\title{
Tolerance of Sugarcane Cultivars to Chemical Eradication ${ }^{1}$
}

\author{
Tolerância de Cultivares de Cana-de-Açúcar à Erradicação Química
}

\begin{abstract}
ADRIANO, R.C. ${ }^{2}$, AZANIA, C.A.M. ${ }^{3}$, PINTO, L.R. ${ }^{4}$, PERECIN, D. ${ }^{5}$, and AZANIA, A.A.P.M. ${ }^{6}$
ABSTRACT - Knowledge of the minimum rate of glyphosate required to eradicate sugarcane ratoons can reduce the amount of herbicide used. To confirm this hypothesis, this study aimed to investigate the tolerance of different sugarcane cultivars to chemical eradication, at different glyphosate rates. The experiment was conducted in a randomized block design in a split-plot scheme, with four replications. The sugarcane cultivars (IACSP94-2094, IACSP942101, IACSP93-3046, IACSP94-4004, IAC86-2480, and RB72454) were allocated in plots and the glyphosate rates $\left(0,1,440,2,160,2,880,3,600\right.$, and 4,320 $\left.\mathrm{gha}^{-1}\right)$, in the sub plots. The traits evaluated were signs of poisoning symptoms; total chlorophyll content, plant height, percentage of dead tillers, and dry weight of the plants. At 45 days after application (DAA), the glyphosate rate of $1,440 \mathrm{~g}$ a.e. $\mathrm{ha}^{-1}$ eradicated the cultivars IACSP94-2094 and IACSP942101, as well as RB72454 with application of 2,160 ga.e. ha-1. Application of glyphosate 2,880 g a.e. ha-1 eradicated both IACSP93-3046 and IAC86-2480 and glyphosate 3,600 g a.e. ha${ }^{1}$ eradicated IACSP94-4004. The most tolerant cultivar was IACSP94-4004, eradicated at the rate of $3,600 \mathrm{~g}$. a.e. ha ${ }^{-1}$. This confirms the hypothesis that knowing the cultivar's tolerance leads, in practice, to a smaller amount of herbicide applied to the environment, which also reduces production costs.
\end{abstract}

Keywords: glyphosate, sugarcane renovation, ratoons, Saccharum spp.

\begin{abstract}
RESUMO - O conhecimento da dose minima de glyphosate utilizada na erradicação das soqueiras de cana-de-açúcar traz como beneficio a redução na quantidade do herbicida. Para comprovar essa hipótese, o objetivo desta pesquisa foi estudar a tolerância das soqueiras de cultivares de cana-deaçúcar à erradicação quimica, a partir de diferentes doses de glyphosate. O experimento foi instalado em delineamento de blocos casualizados, arranjado em esquema de parcelas subdivididas com quatro repetições. Nas parcelas foram alocadas os cultivares de cana-de-açúcar RB72454, IACSP862480, IACSP93-3046, IACSP94-2094, IACSP94-2101 e IACSP94-4004 e, nas subparcelas, as doses de glyphosate: $0 ; 1.440 ; 2.160 ; 2.880 ; 3.600$ e $4.320 \mathrm{~g}$ e.a. ha-1. As características avaliadas foram sintomas visuais de intoxicação, teor de clorofila total, altura de plantas, porcentagem de perfilhos mortos e massa seca de plantas. Aos 45 dias após a aplicação (DAA), a partir de $1.440 \mathrm{~g}$ e.a. ha-1 do glyphosate, os cultivares IACSP94-2094 e IACSP94-2101 foram erradicadas, bem como a RB72454 com aplicação de $2.160 \mathrm{~g}$ e.a. ha ${ }^{-1}$. Nautilização do glyphosate a $2.880 \mathrm{~g}$ e.a. ha ${ }^{-1}$ foram erradicadas a IACSP93-3046 e IAC86-2480. O cultivar de maior tolerância foi IACSP94-4004, erradicado a partir de $3.600 \mathrm{~g}$ e.a. ha-1. Dessa forma, confirma-se a hipótese inicial do trabalho, de que, ao se conhecer a tolerância do cultivar, a conseqüência prática é a menor quantidade de herbicida aplicada no ambiente, o que implica também redução de custo ao produtor.
\end{abstract}

Palavras-chave: glyphosate, reforma de canavial, soqueiras, Saccharum spp.

Recebido para publicação em 17.10.2012 e aprovado em 13.2.2013.

2 Agronomist, M.Sc. in Tropical and Subtropical Agriculture, Instituto Agronômico/Centro de Cana, Rodov. Pref. Antonio Duarte Nogueira, km 321, 14032-800, Ribeirão Preto, SP, <rc.adriano@yahoo.com.br>; ${ }^{3}$ Agronomist, PhD., PqC, Inst. Agronômico/Centro de Cana, Rodov. Pref. Antonio Duarte Nogueira, Km 321, 14032-800, Ribeirão Preto-SP, <azania@iac.sp.gov.br>; ${ }^{4}$ Agronomist, Ph.D., PqC., Inst. Agronômico/Centro de Cana, Ribeirão Preto, <lurossini@iac.sp.gov.br>; ${ }^{5}$ Agronomist, Ph.D., Full Professor, Fac. Ciênc. Agr. e Vet. Jaboticabal, Via de Acesso Prof. Paulo Donato Castellane s/n, 14884-900 Jaboticabal-SP, <perecin@fcav.unesp.br>; ${ }^{6}$ Biologist, PhD., PqC., Inst. Agronômico/Centro de Cana, Rodov. Pref. Antonio Duarte Nogueira, Km 321, $14032-800$ Ribeirão Preto-SP, <andrea.azania@hotmail.com>.

Planta Daninha, Viçosa-MG, v. 31, n. 2, p. 379-386, 2013 


\section{INTRODUCTION}

Yield of sugarcane ratoons tends to gradually decrease as the number of harvests increases; thus, crops have to be renovated. According to CONAB (2012), in the State of São Paulo alone, the renovation of 576,629 ha is expected between 2012 and 2013. In the other regions of Brazil, other 379,743 ha have to be renovated in the same period.

Degeneration over successive years of production makes renovation of sugarcane essential for a wide range of factors which are often complex. To Pacheco \& Cantalice (2011), this can occur by soil compaction and consequent difficulty of root development, while Bassinelo et al. (1984) reported that this situation may be associated with phytosanitary issues. Procópio et al. (2011) correlated it with weed-crop competition, and Salvi et al. (2007), with the fact that ratoons are uprooted during mechanical harvesting.

Thus, ratoons are destroyed when degeneration reduces their yield to levels that no longer allow for profitability. Management can be mechanical or chemical; the latter is used more frequently because it is practical.

According to Silva et al. (2006), glyphosate is the most widely used herbicide in the chemical eradication of ratoons. This product inhibits the enzyme 5-enolpyruvyl-shikimate3-phosphate synthase (EPSPS), a precursor of aromatic amino acids phenylalanine, tyrosine and tryptophan, essential for protein synthesis (Kruse et al.; 2000). Because it is not absorbed by the roots of plants (Rodrigues \& Almeida, 2011), glyphosate can be safely used in sugarcane fields that will be replaced by other crops.

Commercially, the application of 1,800 g a.e. ha ${ }^{-1}$ glyphosate (Rodrigues \& Almeida, 2011) is recommended to eradicate ratoons, but little is known, in Brazil, about the tolerance of sugarcane cultivars to herbicides (Souza, 2009), particularly to glyphosate. In the literature, studies reported up to 2,880 g a.e.ha ${ }^{-1}$ as the rate for the eradication of cultivars (Bacchi \& Rolim 1981), which is still used by producers.

However, knowledge of the degree of cultivar tolerance to glyphosate can reduce production costs and the amount of herbicide to be applied; thus, it also brings benefits to the environment. In this context, the hypothesis underpinning this study is that knowledge of the minimal effective rate to eradicate a particular sugarcane cultivar brings benefits such as reduction of the amount of herbicide to be applied. To prove this hypothesis, the aim of this research was to study the tolerance of sugarcane cultivars to chemical eradication at different glyphosate rates.

\section{MATERIAL AND METHODS}

The experiment was conducted in fifthratoon sugar cane, grown in Oxisol of a very clayey textural class $\left(544 \mathrm{~g} \mathrm{~kg}^{-1}\right.$ clay, $348 \mathrm{~g} \mathrm{~kg}^{-1}$ silt and $108 \mathrm{~g} \mathrm{~kg}^{-1}$ sand), located at 621 meters above sea level. The local climate has dry winters and wet summers, and it is considered to be Cwa, according to the Köppen classification.

The experiment was conducted in randomized blocks, arranged in a split-plot design with four replications. Cultivars RB72454, IACSP86-2480 IACSP93-3046, IACSP94-2094, IACSP94-2101 and IACSP944004 were allocated to the plots, and the herbicide-free control and the glyphosate rates of 1,$440 ; 2,160 ; 2,880 ; 3,600$ and 4,320 g a.e. ha $^{-1}$ were allocated to the subplots. The plots consisted of five sugarcane rows measuring $60 \times 1.50 \mathrm{~m}$, and the subplots consisted of five $8 \times 1.50 \mathrm{~m}$ rows; the variables were evaluated only in three central rows within the floor area $\left(36 \mathrm{~m}^{2}\right)$.

The crop was planted in March 2005 and farmed until August 2010, totaling five mechanical harvests. Height was monitored periodically after the last harvest, and glyphosate was applied when the plants reached $41.3 \mathrm{~cm}$, as proposed in the experiment design. During the experimental period, $456 \mathrm{~mm}$ of rainfall was recorded, with an average temperature of $25.9^{\circ} \mathrm{C}$. These conditions certainly favored plant metabolism.

Glyphosate was applied on December 10th, 2010 with $\mathrm{a} \mathrm{CO}_{2}$-pressurized backpack sprayer outfitted with four flat fan spray nozzles (TT110/02), spaced at $0.50 \mathrm{~m}$. The pressure of the sprayer was $2.1 \mathrm{kgf} \mathrm{cm}^{-2}$, which provided spray volume of $240 \mathrm{~L} \mathrm{ha}^{-1}$. The application 
began at 8:35 a.m., when air temperature was $29{ }^{\circ} \mathrm{C}$; relative humidity, $61.70 \%$; and wind speed, $6.70 \mathrm{~km} \mathrm{~h}^{-1}$, and there were no clouds. It finished at 2:45 p.m., when air temperature was $35.7{ }^{\circ} \mathrm{C}$; relative humidity, $38 \%$; wind speed, $1.60 \mathrm{~km} \mathrm{~h}^{-1}$; and cloudiness, $65 \%$.

The variables evaluated were poisoning symptoms, total chlorophyll content, plant height, percentage of dead tillers and plant dry weight. Poisoning symptoms were evaluated at 10, 27 and 45 days after application (DAA) through visual observation of the shoots, and scores were assigned according to a percentage scale, where $0 \%$ corresponds to the absence of injuries and $100 \%$, to plant death. Total chlorophyll content was measured at 10 DAA, through a Falker ClorofiLOG $\mathbb{R}$ CFL 1030 electronic meter, and measurements were made in the middle third of the leaf +3 of ten plants randomly selected in the floor area of each subplot.

Plant height was checked at 10 and 45 DAA by measuring the length close to the ground until the ligule of the last completely expanded leaf; ten plants were selected in the floor area of each subplot. At 45 DAA, the percentage of dead tillers (\% DT) was estimated with the expression: DT $=100 \%$ - [(number of live tillers at 45 DAA $\times 100$ )/number of live tillers before application]. For this purpose, the number of live tillers had to be counted in the three central rows of each plot before application and also at 45 DAA. Dry weight was also measured at 45 DAA by harvesting the tillers on a linear meter in the groove, in the three central rows of each subplot. Subsequently, they were dried in a forced air circulation oven at $70{ }^{\circ} \mathrm{C}$ until constant weight. Because the number of tillers harvested was taken into consideration, dry weight could be measured in grams per plant.

The variables evaluated were submitted to the F-test for analysis of variance, and the treatment means were compared by Student's t-test at 1 and $5 \%$ probability, after the choice of orthogonal contrasts.

\section{RESULTS AND DISCUSSION}

There was significant plant growth in the control treatment; a height of $41.3 \mathrm{~cm}$ was observed at first, and after 45 days, $82.1 \mathrm{~cm}$ was measured on average, whereas glyphosate was observed to act quickly in the treatments, because the plants had significant poisoning symptoms at 10 DAA.

Tolerance of sugarcane cultivars to several herbicides can be associated with the stage of sugarcane development (Ferreira et al., 2005). Ferreira et al. (2005) also associated leaf morphology and chemical composition of the epicuticular wax present in the leaves with the degree of sensitivity of sugarcane cultivars to herbicides.

Table 1 shows that, at 10 DAA, the cultivar IACSP94-2094 showed the most severe poisoning symptoms among cultivars. The assigned scores resulted in an average of $81.75 \%$; a rate of $2,160 \mathrm{~g}$ a.e. ha ${ }^{-1}$ of glyphosate was sufficient to cause as much poisoning as 4,320 g a.e. ha ${ }^{-1}$. In contrast, IAC86-2480 had the lowest average $(33.25 \%)$, and from a rate of 2,880 g a.e. ha $^{-1}$, poisoning symptoms were similar to those with the highest rate of glyphosate. The symptom observed in this assessment was the yellowing of leaves.

In the assessment at 27 DAA, IACSP942094 still remained with the highest average attributed to poisoning symptoms $(98.25 \%)$; as at 10 DAA, glyphosate applied from 2,160 g a.e. ha ${ }^{1}$ was also sufficient to promote a rate of poisoning similar to the highest rate used (4,320 g a.e. ha- $\left.{ }^{-1}\right)$. However, IAC94-4004 showed the lowest average $(76.25 \%)$, but none of the rates had a similar score to the highest rate of glyphosate (Table 1). In this assessment, more intense yellowing was observed on the leaves, and necroses were present in almost the entire leaf surface, showing the progress of the poisoning symptoms.

Therefore, at 45 DAA, the yellow color of the leaves evolved to necrosis and allowed grading higher poisoning scores (Table 1). Thus, as in previous assessments, IACSP942094 showed more severe symptoms and was graded at $97.25 \%$, and a rate of the herbicide from 1,440 g a.e. ha-1 was sufficient to provide poisoning symptoms similar to those of the highest rate. Symptoms in IACSP94-2101 were also similar.

In contrast, IACSP94-4004 remained with the lowest score given to the poisoning 
Table 1 - Analysis of contrasts of poisoning symptoms among the highest rate of glyphosate and the others applied to eradicate sugarcane cultivars. 2010

\begin{tabular}{|c|c|c|c|c|c|c|}
\hline \multirow{2}{*}{ Cultivars } & \multirow{2}{*}{ Means $^{\underline{1}}$} & \multicolumn{5}{|c|}{ Scores attributed to poisoning symptoms (\%) } \\
\hline & & 4320 vs 0 & 4320 vs 1440 & 4320 vs 2160 & 4320 vs 2880 & 4320 vs 3600 \\
\hline \multicolumn{7}{|c|}{10 DAA } \\
\hline IACSP94-2094 & 81.75 & 85 vs $0 * *$ & 85 vs $68.75^{*}$ & 85 vs $78.75^{\text {ns }}$ & 85 vs $91.25^{\mathrm{ns}}$ & $85 \mathrm{vs} 85^{\text {ns }}$ \\
\hline IACSP94-2101 & 72.25 & 85 vs $0 * *$ & 85 vs $50 * *$ & 85 vs $65^{* *}$ & 85 vs $80^{\text {ns }}$ & 85 vs $81.25^{\mathrm{ns}}$ \\
\hline IACSP93-3046 & 45.25 & 45 vs $0 * *$ & 45 vs $37.5^{\text {ns }}$ & 45 vs $40^{\text {ns }}$ & 45 vs $47.5^{\text {ns }}$ & 45 vs $56.25^{\mathrm{ns}}$ \\
\hline IACSP94-4004 & 38.35 & 47.5 vs $0 * *$ & 47.5 vs $23.75^{* *}$ & 47.5 vs $36.25^{\mathrm{ns}}$ & 47.5 vs $33.75^{\mathrm{ns}}$ & 47.5 vs $51.25^{\mathrm{ns}}$ \\
\hline RB72454 & 57.75 & 68.75 vs $0 * *$ & 68.75 vs $33.75^{* *}$ & 68.75 vs $52.5^{*}$ & 68.75 vs $61.25^{\mathrm{ns}}$ & 68.75 vs $72.5^{\text {ns }}$ \\
\hline IAC86-2480 & 33.25 & 43.75 vs $0 * *$ & 43.75 vs $20^{* *}$ & 43.75 vs $27.5^{*}$ & 43.75 vs $32.5^{\mathrm{ns}}$ & 43.75 vs $42.5^{\mathrm{ns}}$ \\
\hline \multicolumn{7}{|c|}{27 DAA } \\
\hline IACSP94-2094 & 98.25 & 100 vs $0 * *$ & 100 vs $92.5^{*}$ & 100 vs $98.75^{\mathrm{ns}}$ & 100 vs $100^{\mathrm{ns}}$ & 100 vs $100^{\mathrm{ns}}$ \\
\hline IACSP94-2101 & 97.50 & 100 vs $0 * *$ & 100 vs $91.25^{* *}$ & 100 vs $98.75^{* *}$ & 100 vs $100^{\mathrm{ns}}$ & 100 vs $97.5^{\mathrm{ns}}$ \\
\hline IACSP93-3046 & 95.25 & 100 vs $0 * *$ & 100 vs $85^{*}$ & 100 vs $92.5^{*}$ & 100 vs $98.75^{\mathrm{ns}}$ & 100 vs $100^{\mathrm{ns}}$ \\
\hline IACSP94-4004 & 76.25 & 95 vs $0 * *$ & 95 vs $37.5^{* *}$ & 95 vs $75^{*}$ & 95 vs $86.25^{*}$ & 95 vs $87.5^{*}$ \\
\hline RB72454 & 93.25 & 100 vs $0 * *$ & 100 vs $72.5^{* *}$ & 100 vs $96.25^{\text {ns }}$ & 100 vs $97.5^{\mathrm{ns}}$ & 100 vs $100^{\mathrm{ns}}$ \\
\hline IAC86-2480 & 82.50 & 98.75 vs $0 * *$ & 98.75 vs $55^{* *}$ & 98.75 vs $72.5^{* *}$ & 98.75 vs $91.25^{*}$ & 98.75 vs $95^{\mathrm{ns}}$ \\
\hline \multicolumn{7}{|c|}{45 DAA } \\
\hline IACSP94-2094 & 97.25 & 97.5 vs $0^{* *}$ & 97.5 vs $92.5^{\mathrm{ns}}$ & 97.5 vs $97.5^{\mathrm{ns}}$ & 97.5 vs $98.75^{\mathrm{ns}}$ & 97.5 vs $100^{\text {ns }}$ \\
\hline IACSP94-2101 & 99.50 & 100 vs $0 * *$ & 100 vs $98.75^{\text {ns }}$ & 100 vs $98.75^{\text {ns }}$ & 100 vs $100^{\mathrm{ns}}$ & 100 vs $100^{\mathrm{ns}}$ \\
\hline IACSP93-3046 & 94.00 & 97.5 vs $0^{* *}$ & 97.5 vs $90^{*}$ & 97.5 vs $90^{*}$ & 97.5 vs $95^{\text {ns }}$ & 97.5 vs $97.5^{\mathrm{ns}}$ \\
\hline IACSP94-4004 & 82.50 & 95 vs $0 * *$ & 95 vs $57.5^{* *}$ & 95 vs $83.75^{* *}$ & 95 vs $87.5^{*}$ & 95 vs $88.75^{\text {ns }}$ \\
\hline RB72454 & 95.50 & 100 vs $0 * *$ & 100 vs $86.25^{* *}$ & 100 vs $95^{\mathrm{ns}}$ & 100 vs $97.5^{\mathrm{ns}}$ & 100 vs $98.75^{\mathrm{ns}}$ \\
\hline IAC $86-2480$ & 87.25 & 95 vs $0 * *$ & 95 vs $75^{* *}$ & 95 vs $86.25^{*}$ & 95 vs $88.75^{\mathrm{ns}}$ & 95 vs $91.25^{\mathrm{ns}}$ \\
\hline \multicolumn{7}{|c|}{ PS at 10 DAA: $\mathrm{CV}=19.16 ; \mathrm{F}_{\text {Cultivar }}=81.01 * * ; \mathrm{F}_{\text {Rate }}=184.53 * * ;$ Cultivar*Rate $=4.40 * * ; \mathrm{LSD}_{\text {Cultivar }}=2.13 ; \mathrm{LSD}_{\text {Rate }}=1.9 .9$} \\
\hline \multicolumn{7}{|c|}{ PS at 27 DAA: $C V=5.83 ; \mathrm{F}_{\text {Cultivar }}=70.14^{* *} ; \mathrm{F}_{\text {Rate }}=1813.77^{* *} ;$ Cultivar*Rate $=14.66^{* *} ; \mathrm{LSD}_{\text {Cultivar }}=2.13 ; \mathrm{LSD}_{\text {Rate }}=1.99$} \\
\hline \multicolumn{7}{|c|}{ PS at 45 DAA: $\mathrm{CV}=6.38 ; \mathrm{F}_{\text {Cultivar }}=27.2^{* *} ; \mathrm{F}_{\text {Rate }}=1443.08^{* *} ;$ Cultivar*Rate $=4.15^{* *} ; \mathrm{LSD}_{\text {Cultivar }}=2.13 ; \mathrm{LSD}_{\text {Rate }}=1.99$} \\
\hline
\end{tabular}

${ }^{1 /}$ Mean considering treatments with glyphosate application. $\mathrm{PS}=$ poisoning symptoms.

symptoms $(82.50 \%)$, and only the rate of $3,600 \mathrm{~g}$ a.e. $\mathrm{ha}^{-1}$ produced symptoms similar to those for the maximum rate $\left(4,320 \mathrm{~g}\right.$ a.e. $\left.\mathrm{ha}^{-1}\right)$. The results showed that the minimal rate of glyphosate is different for each cultivar: while IACSP94-20494-2101 and IACSP94 could be graded above $97 \%$ for poisoning symptoms, IACSP94-4004 achieved 82.5\%.

The poisoning symptoms are due to the high mobility of the glyphosate through the symplast cell; afterwards, as it penetrates into the phloem, glyphosate is translocated throughout the plant. However, the herbicide accumulates more strongly in roots and meristematic regions (Rodrigues \& Almeida, 2011). The injuries observed in this research are similar to those observed by Tuffi Santos et al. (2009), who studied the effects of simulated drift in eucalyptus plants. In irrigated rice, Ferreira et al. (2006) found that plant injury increased as the amount of glyphosate applied increased, and that the symptoms were growth interruption and loss of the typical green color of the leaves.

At 10 DAA, the total chlorophyll content of the cultivars was also reduced due to the effects of glyphosate (Table 2). For both IACSP94-2094 and IAC86-2480, respectively with the highest $(81.75 \%)$ and lowest $(33.25 \%)$ scores attributed to the poisoning symptoms, chlorophyll content changed only from the rate of 2,160 g a.e. ha- ${ }^{-1}$ of glyphosate. The exception was RB72454, because it was the only cultivar that showed a reduction of chlorophyll content from the minimum rate $\left(1,440 \mathrm{~g}\right.$ a.e. $\left.\mathrm{ha}^{-1}\right)$, although it was rated with $57.75 \%$ of poisoning. 
As the poisoning symptoms were intensified at 27 to 45 DAA, it was not possible to measure new chlorophyll contents because the leaves were very dry. The gradual onset of the effects of glyphosate on plants by reducing the referred content was also observed by Meschede et al. (2011). According to Siqueira et al. (1999), this occurs because glyphosate inhibits the synthesis of ä-aminolevulinate acid, a precursor of chlorophyll, which is associated with the efficiency of the photosynthesis process according to Lopes et al. (2009). As a result, the least interference in the process affects plant development.

Also at 10 DAA, although changes on the chlorophyll content and poisoning symptoms were recorded, differences in plant height could not be observed (Table 3). Only at 45 DAA plant growth was observed to have stopped, because height was similar in both the lowest $\left(1,440\right.$ g a.e. ha $\left.{ }^{-1}\right)$ and the largest

Table 2 - Analysis of contrasts of total chlorophyll at 10 DAA between the highest rate of glyphosate and the others applied to eradicate sugarcane cultivars. 2010

\begin{tabular}{|c|c|c|c|c|c|c|}
\hline \multirow{3}{*}{ Cultivars } & \multirow{3}{*}{ Means $^{\underline{1}}$} & \multicolumn{5}{|c|}{ Chlorophyll (RU) } \\
\hline & & 4320 vs 0 & 4320 vs 1440 & 4320 vs 2160 & 4320 vs 2880 & 4320 vs 3600 \\
\hline & & \multicolumn{5}{|c|}{ "Total" chlorophyll } \\
\hline IACSP94-2094 & 30.29 & 25.17 vs $51.41 * *$ & 25.17 vs $42.99 * *$ & 25.17 vs $28.26^{\mathrm{ns}}$ & 25.17 vs $27.30^{\text {ns }}$ & 25.17 vs $27.75^{\text {ns }}$ \\
\hline IACSP94-2101 & 14.35 & 11.89 vs $47.13^{* *}$ & 11.89 vs $20.66^{*}$ & 11.89 vs $13.83^{\mathrm{ns}}$ & 11.89 vs $12.57^{\mathrm{ns}}$ & $11.89 \mathrm{vs} 12.81^{\mathrm{ns}}$ \\
\hline IACSP93-3046 & 22.60 & 19.19 vs $54.11^{* *}$ & 19.19 vs $28.56^{*}$ & 19.19 vs $22.84^{\mathrm{ns}}$ & 19.19 vs $20.41^{\mathrm{ns}}$ & 19.19 vs $22.02^{\mathrm{ns}}$ \\
\hline IACSP94-4004 & 35.28 & 28.16 vs $51.96^{* *}$ & 28.16 vs $40.06^{* *}$ & 28.16 vs $33.88^{\text {ns }}$ & 28.16 vs $37.01^{*}$ & $28.16 \mathrm{vs} 37.31^{\mathrm{ns}}$ \\
\hline RB72454 & 20.76 & 17.7 vs $50.83^{* *}$ & 17.7 vs $24.62^{\mathrm{ns}}$ & 17.7 vs $24.89^{\text {ns }}$ & 17.7 vs $18.06^{\mathrm{ns}}$ & 17.7 vs $18.52^{\text {ns }}$ \\
\hline IAC86-2480 & 29.87 & 25.31 vs $39.99 * *$ & 25.31 vs $39.37 * *$ & 25.31 vs $30.46^{\mathrm{ns}}$ & 25.31 vs $28.91^{\mathrm{ns}}$ & 25.31 vs $25.31^{\mathrm{ns}}$ \\
\hline
\end{tabular}

$1 / /$ Mean considering treatments with glyphosate application. $\mathrm{RU}=$ relative units.

Table 3 - Analysis of contrasts of plant height between the highest rate of glyphosate and the others applied to eradicate sugarcane cultivars. 2010

\begin{tabular}{|c|c|c|c|c|c|c|}
\hline \multirow{3}{*}{ Cultivars } & \multirow{3}{*}{ Means ${ }^{\underline{1}}$} & \multicolumn{5}{|c|}{ Plant Height $(\mathrm{cm})$} \\
\hline & & 4320 vs 0 & 4320 vs 1440 & 4320 vs 2160 & 4320 vs 2880 & 4320 vs 3600 \\
\hline & & \multicolumn{5}{|c|}{$10 \mathrm{DAA}$} \\
\hline IACSP94-2094 & 50.70 & 48.45 vs $50.30^{\mathrm{ns}}$ & 48.45 vs $48.53^{\mathrm{ns}}$ & 48.45 vs $49.80^{\mathrm{ns}}$ & 48.45 vs $51.53^{\mathrm{ns}}$ & 48.45 vs $55.20^{\mathrm{ns}}$ \\
\hline IACSP94-2101 & 46.63 & 45.50 vs $46.68^{\mathrm{ns}}$ & $45.50 \mathrm{vs} 47.43^{\mathrm{ns}}$ & $45.50 \mathrm{vs} 43.70^{\mathrm{ns}}$ & 45.50 vs $49.48^{\text {ns }}$ & $45.50 \mathrm{vs} 47.03^{\mathrm{ns}}$ \\
\hline IACSP93-3046 & 37.40 & 33.65 vs $41.13^{\mathrm{ns}}$ & 33.65 vs $36.18^{\text {ns }}$ & 33.65 vs $43.50^{\mathrm{ns}}$ & 33.65 vs $37.68^{\text {ns }}$ & 33.65 vs $36.15^{\mathrm{ns}}$ \\
\hline IACSP94-4004 & 43.26 & 40.78 vs $58.53^{*}$ & 40.78 vs $41.95^{\text {ns }}$ & 40.78 vs $44.13^{\mathrm{ns}}$ & 40.78 vs $45.53^{\text {ns }}$ & 40.78 vs $43.95^{\mathrm{ns}}$ \\
\hline RB72454 & 42.94 & $42.38 \mathrm{vs} 44.45^{\mathrm{ns}}$ & $42.38 \mathrm{vs} 44.30^{\mathrm{ns}}$ & 42.38 vs $41.80^{\mathrm{ns}}$ & 42.38 vs $45.58^{\mathrm{ns}}$ & 42.38 vs $40.68^{\mathrm{ns}}$ \\
\hline \multirow[t]{2}{*}{ IAC86-2480 } & 38.13 & 36.68 vs $38.45^{\mathrm{ns}}$ & 36.68 vs $38.90^{\mathrm{ns}}$ & 36.68 vs $37.70^{\mathrm{ns}}$ & 36.68 vs $38.80^{\text {ns }}$ & $36.68 \mathrm{vs} 38.55^{\mathrm{ns}}$ \\
\hline & & \multicolumn{5}{|c|}{$45 \mathrm{DAA}$} \\
\hline IACSP94-2094 & 50.10 & 47.88 vs $82.48^{* *}$ & 47.88 vs $48.15^{\mathrm{ns}}$ & 47.88 vs $52.93^{\mathrm{ns}}$ & 47.88 vs $54.50^{\mathrm{ns}}$ & 47.88 vs $52.05^{\mathrm{ns}}$ \\
\hline IACSP94-2101 & 45.49 & 46.38 vs $82.03 * *$ & 46.38 vs $44.65^{\mathrm{ns}}$ & 46.38 vs $42.68^{\mathrm{ns}}$ & 46.38 vs $47.90^{\mathrm{ns}}$ & 46.38 vs $45.85^{\mathrm{ns}}$ \\
\hline IACSP93-3046 & 34.66 & 31.68 vs $81.78^{* *}$ & 31.68 vs $34.48^{\text {ns }}$ & 31.68 vs $34.88^{\mathrm{ns}}$ & 31.68 vs $36.00^{\text {ns }}$ & 31.68 vs $36.30^{\mathrm{ns}}$ \\
\hline IACSP94-4004 & 45.90 & 44.38 vs $104.23 * *$ & 44.38 vs $50.23^{\mathrm{ns}}$ & 44.38 vs $49.60^{\mathrm{ns}}$ & 44.38 vs $40.45^{\text {ns }}$ & 44.38 vs $45.03^{\text {ns }}$ \\
\hline RB72454 & 42.13 & 43.18 vs $75.630 * *$ & $43.18 \mathrm{vs} 44.23^{\mathrm{ns}}$ & 43.18 vs $37.90^{\mathrm{ns}}$ & $43.18 \mathrm{vs} 44.55^{\mathrm{ns}}$ & 43.18 vs $40.80^{\mathrm{ns}}$ \\
\hline IAC86-2480 & 38.80 & 37.95 vs $66.450 * *$ & 37.95 vs $36.63^{\text {ns }}$ & 37.95 vs $35.53^{\mathrm{ns}}$ & 37.95 vs $42.50^{\text {ns }}$ & 37.95 vs $41.38^{\mathrm{ns}}$ \\
\hline \multicolumn{7}{|c|}{ 10 DAA: $\mathrm{CV}=13.08 ; \mathrm{F}_{\text {Cultivar }}=18.15^{* *} ; \mathrm{F}_{\text {Rate }}=2.39^{*} ;$ Cultivar*Rate $=1.21^{\text {ns }} ;$ LSD Cultivar $=2.13 ;$ LSD Rate $=1.99$} \\
\hline \multicolumn{7}{|c|}{45 DAA: $\mathrm{CV}=17.10 ; \mathrm{F}_{\text {Cultivar }}=11.90 * * ; \mathrm{F}_{\text {Rate }}=85.38^{* *} ;$ Cultivar* Rate $=1.62^{\text {ns }} ;$ LSD Cultivar $=2.13 ;$ LSD Rate $=1.99$} \\
\hline
\end{tabular}

$1 /$ Mean considering treatments glyphosate application. 
$\left(3,600 \mathrm{~g}\right.$ a.e. $\left.\mathrm{ha}^{-1}\right)$ rates of glyphosate. These assessments only showed the growth of the tillers of the control.

Stagnation in growth was due to the interruption of the EPSPs enzyme by glyphosate. According to Tzin \& Galili (2010), this herbicide blocks the production of aromatic amino acids which are essential for the synthesis of proteins and precursors of secondary metabolites, thus affecting plant growth.

At 45 DAA, the plants showed severe symptoms of poisoning (Table 1) and stagnant height (Table 3), which signaled the senescence of cultivars and the consequent effectiveness of the herbicide and its rates. Cultivars IACSP94-2101 and IACSP942094 can be considered the least tolerant because the minimum rate of the herbicide $\left(1,440 \mathrm{~g}\right.$ a.e $\left.\mathrm{ha}^{-1}\right)$ was sufficient to cause similar tiller mortality to that of the maximum rate (Table 4). In both cultivars, the percentage of tiller mortality was 98.17 and $97.72 \%$, respectively, as shown in Table 4.

In contrast, IACSP94-4004 was more tolerant, because its poisoning symptoms had the lowest score (82.5\%) (Table 1) and also the lowest percentage of dead tillers (80.15\%). An amount of $2.880 \mathrm{~g}$ a.e. ha ${ }^{-1}$ of glyphosate was required for the mortality of the cultivar to be similar to that of the highest rate (Table 4).

For the other cultivars (IACSP93-3046, RB72454 and IAC86-2480), the rate of $2,160 \mathrm{~g}$ a.e. ha ${ }^{-1}$ of the herbicide was enough for the percentage of tiller mortality to be similar to that of the highest rate (Table 4). It should also be noted that the cultivars had high percentage of dead tillers, but it was lower compared to IACSP94-2101 and IACSP94-2094 and higher than that of IACSP94-4004.

As for the percentage of dead tillers, it should be noted that although the controls of all cultivars had low values, there was tiller mortality except for IACSP94-2094, which remained alive (Table 4). According to Otto et al. (2009), sugarcane plants originally have high tiller density, but as the crop develops, only a limited number of these is capable of forming stems. Possibly, the competition process cited by the authors was less intense in the respective cultivars and more intense in the others.

In cultivars IACSP94-2094 and IACSP942101 , at 45 DAA, in addition to more severe injuries (Table 1), stagnant height (Table 3) and great tiller mortality (Table 4), there was also a reduction in dry weight accumulation (Table 5). Also as was observed in the other variables, dry weight accumulation was also reduced from the lowest rate of the herbicide (Table 5). The results showed that the cultivars were less tolerant to glyphosate and were eradicated with a lower amount of herbicide. In contrast, IACSP94-4004 had the highest dry weight accumulation (Table 5). For the cultivars, 2,880 g a.e. ha ${ }^{-1}$ of glyphosate was required for weight accumulation to be similar to that observed in the treatment with the highest rate of the herbicide. When the cultivars IACSP94-2094 and IACSP94-2101 were compared, it was found that the amount

Table 4 - Analysis of contrasts of the percentage of dead tillers between the highest rate of glyphosate and the others applied to eradicate sugarcane cultivars at 45 days after treatment (DAA). 2011

\begin{tabular}{|l|c|c|c|c|c|c|}
\hline \multirow{2}{*}{ Cultivars } & \multirow{2}{*}{ Means $^{1}{ }^{\prime}$} & \multicolumn{5}{|c|}{ Percentage of dead tillers $(\%$ DT) } \\
\cline { 3 - 8 } & & 4320 vs 0 & 4320 vs 1440 & 4320 vs 2160 & 4320 vs 2880 & 4320 vs 3600 \\
\hline IACSP94-2094 & 97.72 & 97.96 vs $0 * *$ & 97.96 vs $92.76^{\text {ns }}$ & 97.96 vs $98.89^{\text {ns }}$ & 97.96 vs $99.94^{\text {ns }}$ & 97.96 vs $99.08^{\text {ns }}$ \\
\hline IACSP94-2101 & 98.17 & 99.88 vs $9.69^{* *}$ & 99.88 vs $91.81^{\text {ns }}$ & 99.88 vs $99.18^{\text {ns }}$ & 99.88 vs $100^{\text {ns }}$ & 99.88 vs $100^{\text {ns }}$ \\
\hline IACSP93-3046 & 93.16 & 97.60 vs $9.47^{* *}$ & 97.60 vs $80.35^{* *}$ & 97.60 vs $92.9^{\text {ns }}$ & 97.60 vs $96.57^{\text {ns }}$ & 97.60 vs $98.38^{\text {ns }}$ \\
\hline IACSP94-4004 & 80,15 & 96.44 vs $6.69^{* *}$ & 96.44 vs $40.30^{* *}$ & 96.44 vs $79.12^{* *}$ & 96.44 vs $92.28^{\text {ns }}$ & 96.44 vs $92.59^{\text {ns }}$ \\
\hline RB72454 & 94.25 & 100 vs $0.27^{* *}$ & 100 vs $78.84^{* *}$ & 100 vs $94.36^{\text {ns }}$ & 100 vs $98.20^{\text {ns }}$ & 100 vs $99.83^{\text {ns }}$ \\
\hline IAC86-2480 & 85.95 & 97.36 vs $2.77^{* *}$ & 97.36 vs $59.53^{* *}$ & 97.36 vs $86.64^{\text {ns }}$ & 97.36 vs $90.66^{\text {ns }}$ & 97.36 vs $95.57^{\text {ns }}$ \\
\hline
\end{tabular}

1/ Mean considering treatments with glyphosate application. 
Table 5 - Analysis of the contrasts of dry weight between the highest rate of glyphosate and the others applied to eradicate sugarcane cultivars. 2011

\begin{tabular}{|c|c|c|c|c|c|c|}
\hline \multirow{2}{*}{ Cultivars } & \multirow{2}{*}{ Means $^{\underline{1} /}$} & \multicolumn{5}{|c|}{ Plant dry weight $^{-1}(\mathrm{~g})$} \\
\hline & & 4320 vs 0 & 4320 vs 1440 & 4320 vs 2160 & 4320 vs 2880 & 4320 vs 3600 \\
\hline IACSP94-2094 & 19.92 & 19.29 vs $31.05^{* *}$ & 19.09 vs $20.9^{\text {ns }}$ & 19.09 vs $21.14^{\mathrm{ns}}$ & 19.09 vs $19.2^{\text {ns }}$ & 19.09 vs $19.29^{\text {ns }}$ \\
\hline IACSP94-2101 & 19.18 & 18.77 vs $32.81 * *$ & 18.77 vs $19.32^{\text {ns }}$ & 18.77 vs $18.12^{\text {ns }}$ & 18.77 vs $18.93^{\text {ns }}$ & 18.77 vs $20.78^{\text {ns }}$ \\
\hline IACSP93-3046 & 23.10 & 20.95 vs $30.9^{* *}$ & 20.95 vs $25.37 *$ & 20.95 vs $23.25^{\text {ns }}$ & 20.95 vs $23.91^{\mathrm{ns}}$ & 20.95 vs $22.02^{\mathrm{ns}}$ \\
\hline IACSP94-4004 & 26.09 & 23.51 vs $40.22 * *$ & 23.51 vs $29.13^{* *}$ & 23.51 vs $28.54^{*}$ & 23.51 vs $24.54^{\mathrm{ns}}$ & 23.51 vs $24.75^{\mathrm{ns}}$ \\
\hline RB72454 & 20.29 & 19.27 vs $34.57 * *$ & 19.27 vs $22.11^{\mathrm{ns}}$ & 19.27 vs $20.37^{\text {ns }}$ & 19.27 vs $20.36^{\text {ns }}$ & 19.27 vs $19.27^{\text {ns }}$ \\
\hline IAC $86-2480$ & 21.60 & 19.92 vs $30.04 * *$ & 19.92 vs $26.53 * *$ & 19.92 vs $20.8^{\text {ns }}$ & 19.92 vs $21.2^{\text {ns }}$ & 19.92 vs $19.55^{\text {ns }}$ \\
\hline \multicolumn{7}{|c|}{ Dry weight at 45 DAA: $C V=11.99 ; \mathrm{F}_{\text {Cultivar }}=19.89^{* *} ; \mathrm{F}_{\text {Rate }}=71.24 * * ;$ Cultivar $*$ Rate $=1.44^{\text {ns }} ;$ LSD $_{\text {Cultivar }}=2.13 ;$ LSD $_{\text {Rate }}=1.99$} \\
\hline \multicolumn{7}{|c|}{ Transformed data: $\sqrt{ }(n+0,5)$; Data in parentheses represent total dry weight $m-1 ; 1 /$ mean considering treatments with glyphosate application. } \\
\hline
\end{tabular}

of herbicide had to be twice as much so that tiller mortality and dry weight accumulation were similar to that of the highest rate.

In cultivars IACSP93-3046, RB72454 and IAC86-2480, dry weight accumulation was reduced from the rate of 2,160 g a.e. $\mathrm{ha}^{-1}$ of glyphosate, while for IACSP94-2094 and IACSP94-2101, the rate of 1,440 g a.e. ha-1 was sufficient for reduction; for IACSP94-4004, 2.880 g a.e. ha ${ }^{-1}$ was required (Table 5 ). The results for dry weight observed in the cultivars corroborate with those found by Zobiole et al. (2010), who studied rates of glyphosateresistant soybeans and found a decreasing rate of dry weight as the rate of herbicide was increased.

The results have highlighted that there are different levels of tolerance to glyphosate among sugarcane cultivars and the least tolerant cultivars (IACSP94-2094 and IACSP942101) were eradicated with half the rate of the herbicide used to eradicate the most tolerant cultivar (IACSP94-4004). Thus, the initial hypothesis is confirmed, that is, knowledge of cultivar tolerance results in a smaler amount of herbicide applied to the environment, which also means reduced production costs.

\section{LITERATURE CITED}

BACCHI, O. O. S.; ROLIM, J. C. Dose letal de glifosato para fins de eliminação química de soqueiras. In: CONGRESSO NACIONAL DA SOCIEDADE DOS TÉCNICOS AÇUCAREIROS E ALCOOLEIROS DO BRASIL, 2., 1981, Rio de Janeiro. Anais... Rio de Janeiro: STAB, 1981. p. $13-20$.
BASSINELO, A. I. et al. Primeiros resultados de estudos de novas variedades de cana-de-açúcar em solos de cerrado. In: CONGRESSO NACIONAL DA STAB, 3., 1984; CONVENÇÃO DAATALAC, 5., 1984, São Paulo. Anais... São Paulo: 1984. p. 206-214

CONAB. Acompanhamento de safra brasileira: canade-açúcar, primeiro levantamento de abril/2012.

Disponível em: <http://www.conab.gov.br>. Acesso em: 27 abr. 2012

FERREIRA, E. A. et al. Sensibilidade de cultivares de canade-açúcar à mistura trifloxysulfuron-sodium + ametryn

Planta Daninha, v. 23, n. 1, p. 93-99, 2005

FERREIRA, F. B. et al. Consequências da deriva simulada do herbicida glyphosate sobre a cultura do arroz irrigado (Oryza sativa L.). R. Bras. Agroci., v. 12, n. 3, p. 309-312, 2006.

FERREIRA, M. O. A eficiência do glifosato na destruição química das socarias de cana-de-açúcar das variedades NA56-79 e CB45-3. STAB, Açúcar, Álcool Subpr., v. 4, n. 5 , p. $46-48,1986$

KRUSE, N. D.; TREZZI, M. M.; VIDAL, R. A. Herbicidas inibidores da EPSPs: Revisão de literatura. R. Bras. Herbic., v. 1, n. 2, p. 139-146, 2000

LOPES, J. P. et al. Análise de crescimento e trocas gasosas na cultura de milho em plantio direto e convencional. Bragantia, v. 68 , n. 4 , p. $839-848,2009$

MESCHEDE, D. K. et al. Alteração físiológica da cana-deaçúcar pela aplicação de glyphosate e sulfumeturon-methyl. Planta Daninha, v. 29, n. 2, p. 413-419, 2011.

OTTO, R. et al. Fitomassa de raízes e da parte aérea da canade-açúcar relacionada à adubação nitrogenada de plantio. Pesq Agropec. Bras., v. 44, n. 4, p. 398-405, 2009.

Planta Daninha, Viçosa-MG v. 31, n. 2, p. 379-386, 2013 
PACHECO, E. P.; CANTALICE, J. R. B. Compressibilidade, resistência a penetração e intervalo hídrico ótimo de um Argissolo Amarelo cultivado com cana-de-açúcar nos Tabuleiros Costeiros de Alagoas. R. Bras. Ci. Solo, v. 35 , n. 2, p. 403-415, 2011.

PROCÓPIO, S. O. et al. Toxicidade de herbicidas utilizados na cultura da cana-de-açúcar à bactéria diazotrófica Azospirillum brasilense. Planta Daninha, v. 29, p. 10791089, 2011. (Número Especial)

RODRIGUES, B. N.; ALMEIDA, F. S. Guia de herbicidas. 6.ed. Londrina: IAPAR, 2011. 700 p.

SALVI, J. V.; MATOS, M. A; MILAN, M. Avaliação do desempenho de dispositivo de corte de base de colhedora de cana-de-açúcar. Eng. Agríc., v. 27, n. 1, p. 201-209, 2007.

SILVA, M. A.; CARLIN, S. D.; CAPUTO, M. M. Tipos de colheita e épocas de aplicação de glifosato na erradicação de soqueiras de cana-de-açúcar. Pesq. Agropec. Bras., v. 41, n. 1 , p. 43-49, 2006.
SIQUEIRA, S. C. et al. Simulação da soja geneticamente modificada tolerante ao glifosato por meio do cultivo de explantes. R. Bras. Fisiol. Veg., v. 11, n. 1, p. 13-20, 1999.

SOUZA, J. R. et al. Tolerância de cultivares de cana-de-açúcar a herbicidas aplicados em pós-emergência. Bragantia, v. 68, n. 4, p. 941-951, 2009.

TUFFI SANTOS, L. D. et al. Leaf anatomy and morphometry in three eucalypt clones treated with glyphosate. Braz. J. Biol., v. 69, n. 1, p. 129-136, 2009.

TZIN, V.; GALILI, G. New insights into the shikimate and aromatic amino acids biosynthesis pathways in plants. Molec. Plant, v. 3, n. 6, p. 956-972, 2010

ZOBIOLE, L. H. S. et al. Water use efficiency and photosynthesis of glyphosate-resistant soybean as affected by glyphosate. Pestic. Biochem. Physiol., v. 97, n. 3, p. 182-193, 2010. 